\title{
Hak Asasi Manusia (HAM) Dalam Penerapan Hukum Islam Di Indonesia
}

\author{
Achmad Suhaili \\ STIQ Wali Songo \\ ahmadsuhaili63494@gmail.com
}

\begin{abstract}
Abstrak
Hak Asasi Manusia (HAM) merupakan hak yang secara alamiah diperoleh seseorang sejak lahir, karena itu HAM sejalan dengan ftrah manusia itu sendiri. HAM pada hakikatnya merupakan anugrah Allah kepada semua manusia. Dilihat dari kodrat manusia, hakekatnya telah dianugerahi hak-hak pokok yang sama oleh Allah SWT. Hak-hak pokok inilah yang disebut sebagai hak asasi manusia (HAM). HAM yang melekat pada diri manusia, bersifat kodrati, universal, dan abadi berkaitan dengan martabat dan harkat manusia itu sendiri. HAM juga menjadi keharusan dari sebuah negara untuk bisa menjaminnya dalam konstitusinya. Karena Hak asasi manusia adalah seperangkat hak yang melekat pada hakikat keberadaan manusia sebagai mahluk Tuhan Yang Maha Esa dan merupakan anugrah-Nya yang wajib dihormati, di jungjung tinggi, di lindungi oleh negara, hukum, pemerintah, dan setiap orang demi kehormatan serta perlindungan harkat martabat manusia. Ajaran Islam meliputi seluruh aspek dari sisi kehidupan manusia, dan tentu saja telah tercakup di dalamnya aturan dan penghargaan yang tinggi terhadap hak asasi manusia (HAM). Namun memang tidak dalam satu dokumen yang terstruktur, tetapi tersebar dalam ayat-ayat suci alQuran dan Sunnah Nabi Muhammad SAW. Dalam hal ini Negara Indonesia yang mayoritas penduduknya adalah Islam, selalu konsisten dalam penerapan Hukum Islam yang senantiasa mensandingkan prinsipnya dengan Nilai-nilai Hak Asasi Manusia yang harus di lindungi oleh Negara dan Pemerintah.
\end{abstract}

\section{A. Pendahuluan}

Dilihat dari kodrat manusia, hakekatnya telah dianugerahi hak-hak pokok yang sama oleh Allah SWT. Hak-hak pokok inilah yang disebut sebagai hak asasi manusia (HAM). HAM yang melekat pada diri manusia, bersifat kodrati, universal, dan abadi berkaitan dengan martabat dan harkat manusia itu sendiri. HAM juga menjadi keharusan dari sebuah negara untuk bisa menjaminnya dalam konstitusinya.

Istilah HAM baru muncul setelah Revolusi Perancis, dimana para tokoh borjuis berkoalisi dengan tokoh-tokoh gereja untuk merampas hak-hak rakyat yang telah mereka miliki sejak lahir. Akibat dari penindasan panjang yang dialami masyarakat Eropa dari kedua kaum ini, munculah perlawanan rakyat dan yang akhirnya berhasil memaksa para raja mengakui aturan tentang hak asasi manusia. Diantaranya adalah pengumuman hak asasi manusia dari Raja John kepada rakyat 
Inggris tahun 1216. Hak asasi ini lalu diadopsi oleh tokoh-tokoh Revolusi Perancis dalam bentuk yang lebih jelas dan luas, serta dideklarasikan pada 26 Agustus 1789.

Di Indonesia penegakan HAM dapat dikatakan kurang berjalan maksimal. Faktor yang berpengaruh pada penegakan HAM di Indonesia terhambat seperti masalah politik, dualisme peradilan, prosedural acara. Bagi masyarakat muslim, belum pernah mengalami penindasan yang dialami Eropa, dimana sistem perundangundangan Islam telah menjamin hak-hak asasi bagi semua orang sesuai dengan aturan umum yang diberikan oleh Allah kepada seluruh umat manusia. Hak asasi dalam pandangan barat tidak dengan sendirinya mengharuskan negara memberi jaminan keamanan atau pendidikan, dan lain sebagainya. Dalam Islam, konsep mengenai HAM sebenarnya telah mempunyai tempat tersendiri dalam pemikiran Islam. Perkembangan wacana demokrasi dengan Islam sebenarnya yang telah mendorong adanya wacana HAM dalam Islam. Karena dalam demokrasi, pengakuan terhadap hak asasi manusia mendapat tempat yang spesial. Berbagai macam pemikiran tentang demokrasi dapat dengan mudah kita temukan didalamnya konsep tentang penegakan HAM.

Bahkan HAM dalam Islam telah dibicarakan sejak empat belas tahun yang lalu (Anas Urbaningrum, 2004;91). Fakta ini mematahkan bahwa Islam tidak memiliki konsep tentang pengakuan HAM. berangkat dari itu makalah ini akan mencoba memberikan sedikit penerangan mengenai wacana HAM dalam Islam.

\section{B. Pengertian Hak Asasi Manusia}

Hak asasi manusia (HAM) adalah seperangkat hak yang melekat pada hakikat keberadaan manusia sebagai mahluk Tuhan Yang Maha Esa dan merupakan anugrah-Nya yang wajib dihormati, di jungjung tinggi, di lindungi oleh negara, hukum, pemerintah, dan setiap orang demi kehormatan serta perlindungan harkat martabat manusia.

Dalam mukadimah Deklarasi Universal Hak-hak Asasi Manusia (Universal Declaration of Human Right) dijelaskan mengenai hak asasi manusia sebagai berikut: 
"Pengakuan atas keseluruhan martabat alami manusia dan hak-hak yang sama dan tidak dapat dipindahkan kepada orang lain dari semua anggota keluarga kemanusiaan adalah dasar kemerdekaan dan keadilan di dunia."1

Hak asasi dalam Islam berbeda dengan hak asasi menurut pengertian yang umum dikenal. Dalam Islam seluruh hak asasi merupakan kewajiban bagi negara maupun individu yang tidak boleh diabaikan. Oleh karena itu, negara bukan saja menahan diri dari menyentuh hak-hak asasi tersebut, melainkan juga mempunyai kewajiban untuk melindungi dan menjamin hak-hak tersebut.

\section{Konsep Hak Asasi Manusia Dalam Hukum Islam}

HAM merupakan hak yang secara alamiah diperoleh seseorang sejak lahir, karena itu HAM sejalan dengan ftrah manusia itu sendiri. HAM pada hakikatnya merupakan anugrah Allah kepada semua manusia.

Menurut Syari'ah, manusia adalah makhluk bebas yang mempunyai tugas dan tanggung jawab, dan karenanya ia juga mempunyai hak dan kebebasan. Dasarnya adalah keadilan yang ditagakkan atas dasar persamaan atau egaliter, tanpa pandang bulu. Artinya, tugas yang diemban tidak akan terwujud tanpa adanya kebebasan, sementara kebebasan secara eksistensial tidak terwujud tanpa adanya tanggung jawab itu sendiri. ${ }^{2}$

Oleh Islam manusia di tempatkan sebagai makhluk yang memilki kemuliaan dan keutamaan, memiliki harkat dan martabat yang tinggi, sebagaimana dinyatakan dalam al-Quran.

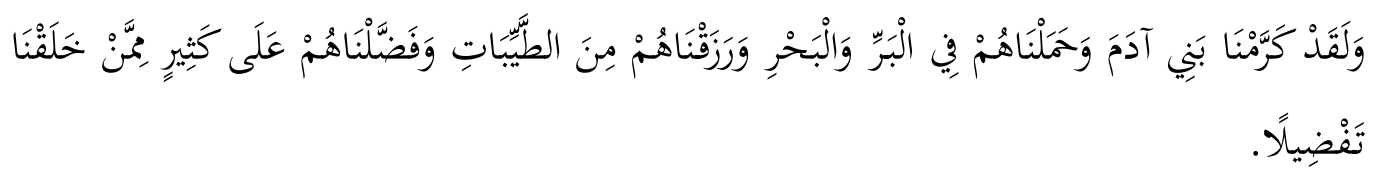

" dan sesungguhnya telah kami muliakan anak-anak adam, kami angkut mereka didaratan dan dilautan, kami beri mereka rezeki dari yang baik-baik dan kami lebihkan mereka dengan kelebihan yang sempurna atas kebanyakan mahluk yang telah kami ciptakan."(Q.S. Al-Isra:70 )

Sistem HAM Islam mengandung prinsip-prinsip dasar tentang persamaan, kebebasan dan penghormatan terhadap sesama manusia Persamaan, artinya Islam

\footnotetext{
1. Dalizar Putra, Hak Asasi Manusia menurut Al-Quran, PT Al-Husna Zikra, Jakarta 2003, hal.32

2. M. Luqman Hakim, Deklarasi Islam tentang HAM, Risalah Gusti, Surabaya, 2000, hal. 12.
} 
memandang semua manusia sama dan mempunyai kedudukan yang sama, satusatunya keunggulan yang dinikmati atas manusia lainnya hanya ditentukan oleh tingkat ketakwaannya. $^{3}$

Hal ini sesuai dengan firman Allah dalam surat al-Hujurat ayat 13:

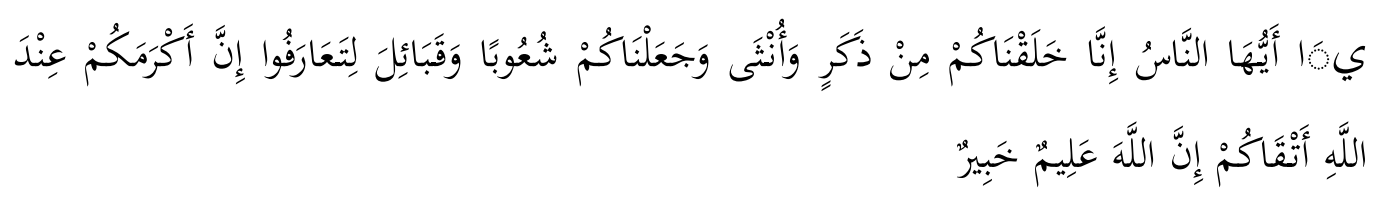

"Hai manusia, sesungguhnya Kami menciptakan kamu dari seorang laki-laki dan seorang perempuan dan menjadikan kamu berbangsa-bangsa dan bersukusuku supaya kamu saling kenal mengenal. Sesungguhnya orang yang paling mulia di antara kamu di sisi Allah ialah orang yang paling bertakwa di antara kamu. Sesungguhnya Allah Maha Mengetahui lagi Maha Mengenal."

Sedangkan kebebasan merupakan elemen penting dari ajaran Islam. Kehadiran Islam memberikan jaminan pada kebebasan manusia agar terhindar dari kesia-siaan dan tekanan, baik yang berkaitan dengan masalah agama, politik dan ideologi. Namun demikian, pemberian kebebasan terhadap mansia bukan berarti mereka dapat menggunakan kebebasan tersebut mutlak, tetapi dalam kebebasan tersebut terkandung hak dan kepentingan orang lain yang harus dihormati juga.

Mengenai penghormatan terhadap sesama manusia, dalam Islam seluruh ras kebangsaan mendapat kehormatan yang sama. Dasar persamaan tersebut sebenarnya merupakan manifestasi dari wujud kemuliaan manusai yang sangat manusiawi. Sebenarnya citra kehormatan tersebut terletak pada keunggulan kemanusiaan, bukan pada superioritas individual dan ras kesukuan. Kehormatan diterapkan secara global melalui solidaritas persamaan secara mutlak. Semua adalah keturunan Adam, jika Adam tercipta dari tanah dan mendapat kehormatan di sisi Allah, maka seluruh anak cucunya pun mendapat kehormatan yang sama, tanpa terkecuali.

Dalam teologi Islam manusia diciptakan oleh Allah sebagai golongan genus mahluk yang dimuliakan (Q.S Al-Israa:70) dan dia harus dihormati sebagai manusia apapun warna kulit. Dari manapun asalnya, dan apapun agama yang dianut. Sampaisampai Malaikatpun harus menghormatinya (Al-Baqarah: 34, Al-a'raf:11). Bersamaan dengan pemberian status sebagai "mahluk yang unggul"

\footnotetext{
3. Harun Nasution dan Bahtisr Effendi, Hak Asasi Manusia dalam Islam, Yayasan Obor Indonesia, Cet. 5. Jakarta, 2001, hal 124
} 
Pada dasarnya HAM dalam Islam terpusat pada lima hal pokok yang terangkum dalam al-dloruriyat al-khomsah atau yang disebut juga al-huquq alinsaniyah fi al-Islam (hak-hak asasi manusia dalam Islam). Konsep ini mengandung lima hal pokok yang harus dijaga oleh setiap individu, yaitu: ${ }^{4}$

1. Hifdzu al-nafs wa al-ird atau Hak Untuk Hidup (Al-Quran surat AL-An'am : 151)

2. Hifdzu al- 'aql atau Hak Persamaan Derajat (Al-Quran surat AL-Hujurat : 13)

3. Hifdzu al-nasl atau Hak memperoleh keadilan (Al-Quran surat al-Maidah : 2)

4. Hifdzu al mal atau Hak Perlindungan harta/Milik (Al-quran surat AL-Baqarah : 188)

5. Hifdzu al-din atau Hak Kebebasan Beragama (Al-quran surat AL-Baqarah : 256, dan surah Yunus : 99).

Dan masih banyak lagi ayat-ayat al-Quran yang mengisyaratkan hak asasi manusia yang dihormati secara universal. Kelima dharurat ini yang menjadi tiang kehidupan manusia. Tidak akan hidup baik kehidupan manusia kecuali dengan menjaga lima perkara ini. Bahkan kelima hal ini adalah HAM yang dijamin syariat Islam. Oleh karena itu Rasulullah shallallahu 'alaihi wasallam pernah bersabda yang

Artinya:

"Seorang Muslim adalah saudara muslim lainnya. Jangan menzhaliminya dan jangan menyerahkannya. Siapa yang membantu kebutuhan saudaranya maka Allah akan membantu kebutuhannya dan siapa yang menyelamatkan seorang muslim dari satu bencana maka Allah akan selamatkan dari satu bencana di hari kiamat. Siapa yang menutupi aib seorang muslim maka Allah akan tutupi aibnya dihari kiamat." (HR al- Bukhori).

Demikian juga dalam haji Wada' Nabi shallallahu 'alaihi wasallam pernah berkhuthbah yang isinya:

"Wahai Manusia hari apakah ini? Mereka menjawab: hari suci. Beliau bertanya lagi: Dinegeri apakah ini? Mereka menjawab : Negeri suci (tanah suci). Beliau tanya: Pada bulan apa ini? Mereka menjawab: Bulan suci. Lalu beliau bersabda: Sesungguhnya darah, harta dan kehormatan kalian haram seperti sucinya hari kalian ini dinegeri kalian ini dan dibulan kalian ini. Beliau ulang beberapa kali." (HR al- Bukhori).

Secara historis, prinsip-prinsip HAM sudah diaplikasikan oleh nabi Muhammad saw. Pada masa awal kepemimpinan beliau di madinah. Di madinah di samping berfungsi sebagai Rosul, Nabi Muhammad saw juga menjabat sebagai

\footnotetext{
${ }^{4}$ Amir Syarifuddin, Pengertian dan Sumber Hukum Islam dalam Ismail Muhammad Syah, dkk. Filsafat Hukum Islam (Cet. II; Jakarta: Bumi Aksara, 2000), h. 25-26
} 
kepala negara, yang warganya terdiri atas berbagai macam aliran dan golongan yang jauh sebelumnya saling bersengketa dan bermusuhan. Untuk mempersatukan warga majemuk itu diperlukan adanya suatu konsensus yang di wajibakan semua pihak tunduk pada perstujuan bersama( common platform $)$.

Prinsip-prinsip penghormatan terhadap HAM, seperti yang menyangkut keadilan, persamaan derajat, kebebasan beragama dan lainnya tanpa diskriminasi atas dasar ras, warna kulit, jenis kelamin dan agama dapat dijumpai terutama pada ayatayat Makiyah (yang turun selama periode Mekah), Kemudian dalam perjalanan peradaban Islam, para ulama dan sarjana muslim mengembangkan konsep-konsep rasional baik dalam masalah hukum, (yang lazim disebut fiqih) atau teologia (yang sering disebut ilmu kalam), dan disitu mulai terlihat adanya banyak perbedaan persepsi dalam menyikapi HAM di kalangan ulama dan sarjana Islam dan hal ini berlangsung sampai sekarang, ditambah lagi dengan gencarnya Revivalisme Islam dalam dekade terakhir ini. Semangat Revivalisme Islam juga menyentuh tentang HAM. Konsep HAM yang universal ditolak karena dianggap mengandung Bias kepentingan Barat, sebaliknya kemudian diajukan prinsip HAM dalam prinsip Islam dan Formulasi paling modern dari HAM versi Islam ini adalah "Al-Bayan alalami'an huquq al insan fil islam,"5

Islam sebagai agama Samawi, telah meletakkan dasar-dasar teologia dan ajaran-ajaran yang telah diuji-cobakan oleh sang pembawanya sendiri (Nabi Muhammad SAW) dan berhasil meletakkan pengalaman social yang menjunjung tinggi prinsip kemanusiaan dan Hak-hak asasi manusia di tengah-tengah kehidupan masyarakat dengan berbagai tradisi, berbagai agama dan kemajemukkannya. Suritauladan tersebut juga diteruskan oleh penerus selanjutnya. prestasi yang seharusnya dipertahankan ini juga mengalami pasang surut, Bukan karena kelemahan dan kesalahan Teologia atau ajaran Islam yang dibawa dan diajarkan oleh Nabi Muhhammad SAW akan tetapi karena faktor-faktor seperti disebutkan di atas!

Untuk masalah yang menyangkut penerapan HAM dalam Plurarisme agama. Al-Quran dan sunnah Nabi Muhammad saw memberikan bimbingan dan teladan implementasinya kepada para pengikutnya, mulai dari kehidupan berkeluarga hingga

\footnotetext{
5. Deklarasi Internasional tentang Hak-hak asasi manusia dalam Islam, yang disampaikan di paris pada tahun 1981.
} 
kehidupan berbangsa dan bernegara, bahkan pemerintahan atau negara yang pertama kali didirikan oleh Nabi Muhammad dan pengikutnya di madinah adalah sebuah negara dengan keragaman Agama dan suku.

Secara garis besar pandangan para intelektual Muslim dalam menyikapi tentang HAM, dapat dikategorikan menjadi empat kelompok, yaitu: ${ }^{6}$

Pertama, kelompok fundamentalis. tipologi pemikiran kelompok fundamentalis ini menolak HAM international secara penuh, pemikiran kegamaan mereka lebih bersifat apologis, literalis dan romantis

Kedua, kelompok reformis sekuler. Tipologi pemikiran kelompok reformis sekuler ini adalah menerima HAM Internasional tanpa reserve, mengedepankan unsur rasionalitas dan unsur kemanusiaan. Karena kelompok reformis sekuleris ini dalam menyikapi urusan politik dan agama berusaha untuk memisahkannya. Secara umum kelompok ini menganut dan mengamalkan sekulerisme. Tokoh yang paling terkemuka yang dapat dikategorikan kelompok ini adalah Ali Abd Raziq.

Ketiga, kelompok reformis fundamentalis. Kelompok reformis fundamentalis ini menerima HAM secara terbatas (kritis). Pada umumnya kelompok ini berupaya mencari sintesis yang memungkinkan antara nilai-nilai Islam dan nilai-nilai baru (yang datang dari luar Islam) meskipun pada kenyataannya pemikiran ini masih tetap berpegang teguh pada ajaran Islam (yang bersikap teknis praktis) yang bertentangan dengan pemikiran HAM internasional dan nilai-nilai kemanusiaan. Pemikiran ini mempunyai kesamaan dengan tipologi pemikiran fundamentalis, yaitu bersipat teosentris.

Keempat, tipologi kelompok pemikir mutakhir. Ciri dari tipe ini adalah sikap kritis dan obyektif terhadap pemikiran Barat (HAM internasional) dan pemikiran Timur (Islam) secara berimbang. Kelompok ini berupaya mencari nilai autentik dari pemikiran Islam dan Barat. Oleh karena itu tipe ini bisa digolongkan pada Reformis Super Fundamentalis. Di antara tokoh yang membangun pemikiran ini adalah Hasan Hanafi.

\footnotetext{
${ }^{6 .}$ Harun Nasution dan Bahtisr Effendi, Hak Asasi Manusia dalam Islam, Yayasan Obor Indonesia, Cet. 5. Jakarta, 2001, hal 130
} 


\section{Nilai-Nilai HAM dalam Syari’ah/Hukum Islam}

Secara normatif, nilai-nilai HAM dirumuskan oleh PBB dalam sebuah deklarasi yang kemudian dikenal sebagai Deklarasi Hak Asasi Manusia Universal (Universal Declaration of Human Rights) PBB pada 10 Desember 1948. Deklarasi ini disepakati oleh 48 negara dimaksudkan untuk menjadi standar umum yang universal dari hak asasi manusia bagi sleuruh bangsa dan umat manusia. Deklarasi ini menyebutkan seluruh hak dan kebebasan yang dinikmati setiap individu tanpa memandang ras, warna kulit, jenis kelamin, bahasa, agama, opini politik, dan opini lainnya, asal-usul kebangsaan atau sosial, status kekayaan, kelahiran, dan status lainnya. $^{7}$

Deklarasi ini terdiri dari 30 pasal. Secara umum pasal-pasal itu mengatur hakhak yang menjunjung tinggi martabat manusia baik sebagai individu, anggota masyarakat bangsa, maupun masyarakat internasional.

Dilihat dari tujuan, nilai-nilai HAM di atas sangat universal dan baik. Harkat dan martabat manusia dijunjung tinggi terlepas dari perbedaan ras, agama, warna kulit, dan perbedaan lainnya. Dalam konteks ajaran Islam, nilai-nilai itu diakui sebagai sunnatullah.

Islam adalah agama yang universal dan komprehensif yang melingkupi beberapa konsep. Konsep yang dimaksud yaitu aqidah, ibadah, dan muamalat yang masing-masing memuat ajaran keimanan. Aqidah, ibadah dan muamalat, di samping mengandung ajaran keimanan, juga mencakup dimensi ajaran agama Islam yang dilandasi oleh ketentuan-ketentuan berupa syariat atau fikih. ${ }^{8}$

Selanjutnya, di dalam Islam, menurut Abu A'Ala Al-Maududi, ada dua konsep tentang Hak. Pertama, Hak manusia atau huquq al-insān al-dharuriyyah. Kedua, Hak Allah atau huquq Allah. Kedua jenis hak tersebut tidak bisa dipisahkan. Dan hal inilah yang membedakan antara konsep HAM menurut Islam dan HAM menurut perspektif Barat. ${ }^{9}$

Perlu dicatat bahwa inti dari HAM adalah egalitarianisme, demokrasi, persamaan hak di depan hukum, dan keadilan sosial, ekonomi, dan budaya.

\footnotetext{
7. M. Luqman Hakim, Deklarasi Islam tentang HAM, Risalah Gusti, Surabaya, 2000, hal. 54.

8. T. Muhammad Hasbi Ash Shiddieqy, Islam dan Hak Asasi Manusia, PT Pustaka Rizki Putra,Semarang, 1999, hal.50.

9. Abu A'Ala Al-Maududi http://ufukislam.blogspot.com/2009/12/abul-ala-al-maududi.html
} 
Perbedaan, misalnya dalam pandangan Islam, adalah kehendak Allah karena itu segala upaya yang memaksa agar semua manusia itu seragam (satu agama, satu bangsa, satu warna kulit, satu opini politik) adalah penyangkalan terhadap sunnatullah itu. Dalam al-Qur'an Allah menegaskan,:

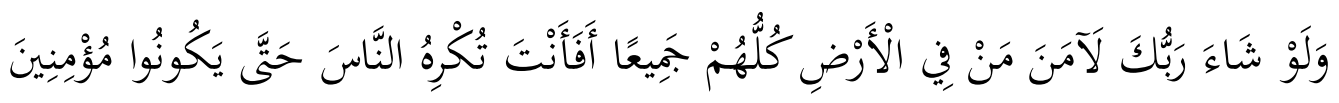

"Dan Jikalau Tuhanmu menghendaki, tentulah beriman semua orang yang di muka bumi seluruhnya. Maka Apakah kamu (hendak) memaksa manusia supaya mereka menjadi orang-orang yang beriman semuanya?" (QS, Yunus : 99)

Kitab tafsir yang sangat dihormati, Tafsir Jalalain ${ }^{10}$, membuat tekanan sentral yang lebih memperjelas ayat ini dengan mengatakan, "hendak kau paksa jugakah orang untuk melakukan apa yang Allah sendiri tidak ingin melakukannya terhadap mereka?"11

Penegasan Jalalain dapat mempertegas bahwa usaha untuk menyamakan semua perbedaan semua umat manusia adalah sebuah tindakan pelanggaran HAM. Ini juga menunjukkan bahwa dengan perbedaan manusia didorong untuk saling menolong dan bekerjasama. Karena itu, sikap menghargai atas perbedaan di antara manusia adalah sikap primordial yang tumbuh secara organik sejak Islam diserukan kepada umat manusia 1500 tahun yang lalu.

Islam menyadari bahwa mengakui perbedaan adalah sikap paling realistis. Hal ini ditegaskan dalam al-Qur'an Surat al-Baqarah ayat 272 "Bukan tugasmu (hai Rasul) memberi petunjuk kepada mereka. Tetapi Allah lah yang memberi petunjuk kepada siapapun yang kekehendaki-Nya". Ayat-ayat ini adalah prinsip HAM dalam beragama dan dalam menghormati perbedaan. Namun demikian, ayat ini menganjurkan agar setiap orang yang beriman harus tetap teguh tanpa harus terpengaruh oleh ajaran yang lain.

Selain prinsip HAM di atas, prinsip-prinsip lain yang bersifat menjunjung tinggi harkat dan martabat manusia adalah kritik Islam atas ketidakadilan, ketimpangan sosial, dan diskriminasi. Nilai-nilai ini adalah juga yang diperjuangkan

10. karya Jalaluddin Muhammad bin Ahmad al-Mahalli $(791 \mathrm{H}-864 \mathrm{H})$ dan Abu al-Fadl Abdur Rahman bin Abu Bakar bin Muhammad Jalaluddin as-Suyuti (849-911 H). Ia disebut Jalalain yang berarti dua (ulama tafsir bernama) Jalal.

11. Jalaluddin Mahalli dan Jalaluddin al-Suyuti, terbit dalam banyak edisi dan tafsir yang saya kutip mengikuti ayat dari QS 10: 99 di atas. 
oleh HAM. Sejak 1500 tahun yang lalu, al-Qur'an menyampaikan kritik ini seperti ketidakadilan ekonomi dalam pernyataan "kekayaan tidak boleh berputar di kalangan orang-orang kaya saja", QS 59:7. Juga aturan zakat dalam QS 9:60 memperkuat bagaimana Islam peduli pada orang-orang tertindas yang perlu ditolong dan ditingkatkan harkat dan martabatnya. Melakukan pembiaran atas nasib orang-orang miskin dan terlantar adalah perbuatan melanggar agama dan HAM.

Selanjutnya, pada level sosial-politik al-Quran ingin menguatkan unit kekeluargaan paling dasar yang terdiri dari kedua orang tua, anak-anak, dan kakeknenek. Unit keluarga adalah dasar keharmonisan di mana harkat manusia mulai ditegakkan. Karena itu al-Qur'an peduli pada aspek ini seperti diterangkan dalam QS, 2: 83, 4:36, 6:161, 17:23, 29:8, dan lain-lain. Karena itu, peningkatan harkat dan martabat manusia hanya bisa bermakna jika dikaitkan dengan aspek keadilan ekonomi, sosial, dan politik. Prinsip-prinsip al-Qur'an di atas mengatur sedemikian rupa sehingga hak-hak manusia tidak dilanggar baik dalam tingkat individu, keluarga, maupun masyarakat. Baik secara ekonomi, sosial, maupun politik.

Jadi, persamaan hak, keadilan, tolong-menolong, dan persamaan di depan hukum adalah prinsip-prinsip kunci yang sangat diperhatikan di dalam Syari'ah. Dalam sejarah peradaban Islam, prinsip-prinsip ini dipegang oleh umat Islam sebagai cara hidup bermasyarakat, berbangsa, dan bernegara.

Dengan prinsip-prinsip yang sangat jelas di atas, maka setiap pemaksaan kehendak, penindasan, diskriminasi, intoleransi, terorisme, dan hal-hal yang menyalahi sunnatullah bukanlah ajaran Islam. Sekalipun hal ini dilakukan oleh oknum umat Islam, namun ini tetap sebagai bukan ajaran Islam. Penegasan ini perlu, karena semua pelanggaran HAM dalam bentuk pemerintahan otoriter (Saddam Hussein Abd al-Majid al-Tikriti, Moammar Abu Minyar Al- Khadafi dan lain-lain), dalam bentuk terorisme, dan dalam bentuk penindasan kaum wanita selalu dialamatkan kepada umat Islam. Terorisme adalah persoalan politik dan ada di setiap agama manapun. Terorisme bukan ajaran agama karena ia bertentangan dengan nilainilai kemanusiaan dan sunnatullah.

Secara normatif, tidak ada agama yang menganjurkan kekerasan, kekejaman, dan pelanggaran atas hak-hak asasi manusia. Dalam konteks ajaran Islam, ia justru menawarkan konsep kerja sama berdasarkan keadilan, saling menghormati, dan 
persaudaraan. Masalah keyakinan adalah masalah Tuhan, yang manusia sendiri tidak memiliki kewenangan untuk mengadili. Hal ini ditegaskan dalam QS An Nahl:125, "Sesungguhnya Tuhanmu jauh lebih mengetahui daripada engkau tentang siapa yang menyimpang dari jalan-Nya dan siapa yang mendapat petunjuk".

Prinsip ini mempertegas bahwa dahulukan penghormatan terhadap HAM dan jangan engkau hiraukan keyakinannya selama ia tidak memusuhi dan melakukan penyerangan. Dengan kata lain, keyakinan yang berbeda jangan menghalangi kerja sama dan saling menghormati di antara manusia. Prinsip al-Qur'an ini menjadi jalan umat Islam untuk menjadi pelopor dalam toleransi dan penegakan hak-hak asasi manusia. Umat Islam semestinya tidak gamang berbicara soal HAM, karena prinsipprinsipnya telah diajarkan dalam al-Qur'an 1500 tahun yang lalu. Kegamangan untuk menegakkan HAM oleh umat Islam justru menandai kemunduran perspektif. ${ }^{12}$

Penggalian prinsip-prinsip HAM dari Syari'ah memang sudah mulai dilakukan oleh sejumlah ulama. Hasilnya adalah munculnya karya-karya tentang HAM. Bahkan dengan pengayaan baru bahwa Hak Asasi Manusia harus satu paket dengan kewajiban asasi manusia. Konsep Syari'ah tentang HAM dan seluk-beluknya masih terus dapat digali. Bahkan bisa ditambahkan ke dalam muatan HAM yang sudah ada. Pengembangan nilai-nilai HAM dengan pengayaan prinsip-prinsip Syari'ah dapat menjadi pilihan masa depan yang selanjutnya membentuk semacam "Teologi Toleransi", "Teologi HAM", atau "Teologi Kerukunan Beragama".

\section{E. Implementasi Hak Asasi Manusia dalam Hukum Islam Di Indonesia}

Al-Quran dan Sunnah sebagai sumber hukum dalam islam memberikan penghargaan yang tinggi terhadap hak asasi manusia. Al-Quran sebagai sumber hukum pertama bagi umat islam telah melatakan dasar-dasar HAM seta kebenaran dan keadilan, jauh sebelum timbul pemikiran mengenai hal tersebut pada masyarakat dunia. Ini dapat di lihat pada ketentuan-ketentuan yang terdapat dal ak-Quran, antara lain:

1. Dalam al-Quran terdapat sekitar 80 ayat tentang hidup, pemeliharaan hidup dan penyediaan sarana kehiduapan, misalnya dalam surat al-Maidah ayat 32 . Disamping itu al-Quran juga berbicara tentang kehormatan dalam ayat 20.

12. T. Muhammad Hasbi Ash Shiddieqy, Islam dan Hak Asasi Manusia, PT Pustaka Rizki Putra,Semarang, 2001, hal.56. 
2. Al-Quran juga menjelaskan sekitar 150 ayat tentang ciptaan makhlukmakhluk, serta tentang persamaan dalam penciptaan, misalnya dalam surat alHujurat ayat 13 .

3. Al-Quran telah mengetengahkan sikap menentang kezaliman dan orang-orang yang berbuat zalim dalam sekitar 320 ayat dan memerintahkan berbuat adil dalam 50 ayat yang di ungkapkan dengan kata-kata : 'adl, qisth dan qishash.

4. Dalam al-Quran terdapat sekitar 10 ayat yang berbicara mengenai larangan memaksa untuk menjamin kebebasan berpikir, berkeyakinan dan mengutamakan aspirasi. Misalnya yang dikemukakan oleh surat al-Kahfi ayat 29.

Begitu juga halnya dengan sunnah nabi. Nabi Muhammad saw telah memberikan tuntunan dan contoh dalam penegakan dan perlindungan terhadap HAM. Hal ini misalnya terlihat dalam perintah nabi yang menyuruh untuk memelihara hak-hak manusia dan hak-hak kemuliaan, walaupun terhadap orang yang berbeda agama, melalui sabda beliau: ${ }^{13}$

“Barang siapa yang mendzalimi seseorang mu'ahid (seorang yang telah dilindungi oleh perjanjian damai) atau mengurangi haknya atau membebaninya diluar batas kesanggupannya atau mengambil sesuatu dari padanya dengan tidak rela hatinya, maka aku lawannya di hari kiamat"

Dalam deklarasi Madinah melalui Piagam Madinah yang terdiri 47 poin merupakan konstitusi atau Undang-undang Dasar (UUD) bagi negara Islam yang pertama didirikan oleh Nabi Muhammad saw sebagai pedoman perilaku sosial, keagamaan, serta perlindungan semua anggota komunitas yang hidup bersama-sama di Madinah.

Fenomena Piagam Madinah yang dijadikan pedoman perilaku sosial, keagamaan, serta perlindungan semua anggota komunitas yang hidup bersama-sama tersebut sampai menimbulkan decak kagum dari seorang sosiolog modern terkemuka berkebangsaan Amerika, yaitu Robert N, Bellah, yang menyatakan bahwa kehidupan Madinah yang sangat menjunjung tinggi HAM, terlampau modern untuk ukuran zaman itu.

Adapun ajaran pokok dalam Piagam Madinah itu adalah: Pertama, interaksi secara baik dengan sesama, baik pemeluk Islam maupun non Muslim. Kedua, saling membantu dalam menghadapi musuh bersama. Ketiga, membela mereka yang

${ }^{13}$ T. Muhammad Hasbi Ash Shiddieqy, Islam dan Hak Asasi Manusia, PT Pustaka Rizki Putra,Semarang, 2001, hal.65. 
teraniaya. Keempat, saling menasihati. Dan kelima menghormati kebebasan beragama. Satu dasar itu yang telah diletakkan oleh Piagam Madinah sebagai landasan bagi kehidupan bernegara untuk masyarakat majemuk di Madinah.

Selain deklarasi Madinah juga terdapat deklarasi Cairo. Deklarasi ini dicetuskan oleh menteri-menteri luar negeri dari negara-negara Organisasi Konferensi Islam (OKI) pada tahun 1990. Peran sentral syari'at Islam sebagai kerangka acuan dan juga pedoman interpretasi dari Deklarasi Kairo ini terwujud pada dokumen itu sendiri, terutama pada dua pasal terakhirnya yang menyatakan bahwa semua hak asasi dan kemerdekaan yang ditetapkan dalam deklarasi ini merupakan subjek dari syari'at islam, syari'at islam adalah satu-satunya sumber acuan untuk menjelaskan dan penjernihan pasal-pasal deklarasi ini (Pasal 23 dan 24).

Dari gambaran di atas baik deklarasi Madinah maupun Deklarasi Kairo, betapa besarnya perhatian Islam terhadap HAM yang dimulai sejak Islam ada sehingga Islam tidak membeda -bedakan latar belakang agama, suku, budaya, strata sosial dan sebagainya.

Begitu pula penserapan atau implementasi Hak Asasi Manusia yang dilaksanakan oleh NKRI dengan dibentuknya Organisasi Negara yaitu Komisi Nasional Hak Asasi Manusia (KOMNASHAM), yang tidak lain mempunyai orientasi melindungi individu dan masyarakat dalam menjalani kehidupannya seharihari, serta menjamin hak persamaan dan keadilan antar sesama. Sehinggi bisa di abstraksikan bahwa Islam, PBB dan NKRI berjalan senada dan seirama dalam penegakan Hak Asasi Manusia demi mewujudkan kesetaraan hidup dan keadilan sosial sehingga kearifan lokal dan tujuan substansi adanya agama dan negara dapat tercapai.

\section{F. Perlindungan Islam terhadap Hak Asasi Manusia}

Adapun hak-hak asasi manusia yang dilindungi oleh hukum islam antar lain: ${ }^{14}$

1. Hak Hidup

Hak hidup adalah hak asasi yang paling utama bagi manusia, yang merupakan karunia dari Allah bagi setiap manusia. Perlindungan hukum Islam terhadap hak hidup manusia dapat dilihat dari ketentuan-ketentuan syari'at yang

\footnotetext{
14. Dalizar Putra, Hak Asasi Manusia menurut al-Qur'an, PT al-Husna Zikra, Jakarta, 2003, hal.
} 
melindungi dan menjungjung tinggi darah dan nyawa manusia, melalui larangan membunuh, ketentuan qishash dan larangan bunuh diri.

Sebagaimana firman Allah dalam surat an-Nisa ayat 93 yang artinya:

"Dan barang siapa membunuh seorang muslim dengan sengaja maka balasannya adalah jahannah, kekal dia didalamnya dan Allah murka atasnya dan melaknatnya serta menyediakan baginya azab yang berat”.

\section{Hak Kebebasan Beragama}

Dalam Islam, kebebasan dan kemerdekaan merupakan HAM, termasuk didalamnya kebebasan menganut agama sesuai dengan keyakinannya. Oleh karena itu, Islam melarang keras adanya pemaksaan keyakinan agama kepada orang yang telah menganut agama lain. Hal ini dijelaskan dalam al-Quran surat al-baqarah ayat 256, yang artinya:

"Tidak ada paksaan untuk (memasuki) agama Islam, sesungguhnya telah jelas jalan yang benar dan jalan yang salah”.

Kemerdekaan beragama terwujud dalam bentuk-bentuk yang meliputi antar lain: ${ }^{15}$

Pertama, tidak ada paksaan untuk memeluk suatu agama atau kepercayaan tertentu atau paksaan untuk menanggalkan suatu agama yang diyakininya.

Kedua, Islam memberikan kekuasaan kepada orang-orang non islam (ahli kitab) untuk melakukan apa yang menjadi hak dan kewajiban atau apa saja yang dibolehkan, asal tidak bertentangan dengan hukum islam.

Ketiga, Islam menjaga kehormatan ahli ktab, bahkan lebih dari itu mereka diberi kemerdekaan untuk mengadakan perdebatan dan bertukar pikiran derta pendapat dalam-dalam batasan-batasan etika perdebatan serta menjauhkan kekerasaan dan paksaan.

Islam telah memberikan respon positif terhadap kebebasan beragama yang tercermin dalam bentuk kerukunan dan toleransi antar pemeluk agama. Hal ini tercermin dalam bentuk larangan memaki sembahan penganut agama lain, meskipun menurut pandangan Islam hal itu termasuk syirik, sebagaimana dikatakan dalam surat al-An'am ayat 108, yang artinya:

"dan jangan kamu memaki sembahan-sembahan yang mereka sembah selain Allah, karena nanti akan memaki Allah dengan melampaui batas tanpa pengetahuan."

\footnotetext{
${ }^{15}$ Dalizar Putra, Hak Asasi Manusia menurut al-Qur'an, PT al-Husna Zikra, Jakarta, 2003, hal. 


\section{Hak atas Keadilan}

Keadilan adalah dasar dari cita-cita islam dan merupakan disiplin mutlak untuk menegakan kehormatan manusia. Dalam hal ini banyak ayat-ayat Quran maupun sunnah yang mengajak untuk mengakkan keadilan, diantaranya pada surat an-Nahl ayat 90, yang artinya:

"sesungguhnya Allah menyuruh kamu berlaku adil dan berbuat kebajikan, memberi kepada kaum kerabat dan Allah melarang perbuatan keji, kemungkaran dan permusuhan."

\section{Hak Persamaan}

Isalm tidak hanya mengakui prinsup kesamaan derajat mutlak diantara manusia tanpa memandang warna kulit, ras atau kebangsaan, melainkan menjadikannya realitas yang penting.

Al-Quran menjelaskan idealisnya tentang persamaan manusia dalam surat al-Hujurat ayat 13 , yang artinya:

"Hai manusia, sesungguhnya Kami menciptakan kamu dari seorang lakilaki dan seorang perempuan dan menjadikan kamu berbangsa-bangsa dan bersuku-suku supaya kamu saling kenal mengenal. Sesungguhnya orang yang paling mulia di antara kamu di sisi Allah ialah orang yang paling bertakwa"

5. Hak mendapatkan Pendidikan

Setiap orang memiliki hak untuk mendapatkan pendidikan dan pengajaran. Setiap orang berhak mendapatkan pendidikan sesuai dengan kesanggupan alminya. Dalam islam, mendapatkan pendidikan bukan hanya merupakan hak, tapi juga merupakan kewajiban bagi setiap manusia, sebagaimana yang dinyatakan oleh hadits nabi saw yang diriwayatkan oleh Bukhari:

"menuntuk ilmu adalah kewajiban bagi setiap muslim"

\section{Hak Kebebasan Berpendapat}

Setiap orang mempunyai hak untuk berpendapat dan menyatakan pendapatnya dalam batasan-batasan yang ditentukan hukum dan norma-norma lainya. Artinya tidak seorangpun diperbolehkan menyebarkan fitnah dan beritaberita yang mengganggu ketertiban umum dan mencemarkan nama baik orang lain.

Kebebasan berpendapat telah dikenal dalam Islam. Sudah merupakan tradisi dikalangan sahabat untuk bertanya kepada Nabi saw tentang beberapa masalah berkenaan dengan perintah Allah yang diwahyukan kepadanya. Apabila nabi menyatakan bahwa dirinya tidak mendapat petunjuk dari Allah, maka para sahabat boleh menyatakan pendapatnya dengan bebas. Hal ini misalnya terlihat 
dalam peristiwa perang badar, dimana Nabi saw memilih suatu tempat khusus yang dianggapnya pantas untuk menyerang musuh, namun sahabat menyarankan mengambil tempat lain dan Nabi pun menyetujuinya, karena tempat itu lebih strategis.

Kebebasan berpendapat juga dijamin dengan adanya lembaga musyawarah dengan rakyat, yang dijelaskan dalam surat asy-Syura ayat 38, yang artinya:

"Dan urusan mereka diputuskan dengan musyawarah diantara mereka".

\section{Hak Kepemilikan}

Islam menjamin hak kepemilikan yang sah dan mengharamkan penggunaan cara apapun untuk mendapatkan harta orang lain yang bukan haknya, sebagaimana firman Allah dalam surat al-Baqarah ayat 188, yang artinya:

"Dan janganlah sebahagian kamu memakan harta sebahagian yang lain di antara kamu dengan jalan yang batil dan (janganlah) kamu membawa (urusan) harta itu kepada hakim, supaya kamu dapat memakan sebahagian daripada harta benda orang lain itu dengan (jalan berbuat) dosa, padahal kamu mengetahui”

\section{Hak Mendapatkan Pekerjaan}

Islam tidak hanya menempatkan bekerja sebagai hak, tetapi juga sebagai kewajiban. Bekerja merupakan kehormatan yang perlu dijamin, sebagaimana sabda nabi saw:

"Tidak ada makanan yang lebih baik yang dimakan seseorang dari pada makanan yang dihasilkan dari tangannya sendiri"'(HR. Bukhari)

Disamping itu islam menjamin hak pekerja:

"Berilah pekerja itu upah sebelum kering keringatnya" (HR. Ibnu Majah)

\section{G. Kesimpulan}

Hak dapat dimaknai sebagai suatu nilai yang diinginkan seseorang untuk melindungi dirinya, agar ia dapat ia memelihara dan meningkatkan kehidupannya dan mengembangkan kepribadiannya. Ketika diberi imbuhan asasi, maka ia sedemikian penting, mendasar, diakui oleh semua peradaban, dan mutlak pemenuhannya.

Karena Hak asasi manusia adalah seperangkat hak yang melekat pada hakikat keberadaan manusia sebagai mahluk Tuhan Yang Maha Esa dan merupakan anugrah-Nya yang wajib dihormati, di jungjung tinggi, di lindungi oleh negara, 
hukum, pemerintah, dan setiap orang demi kehormatan serta perlindungan harkat martabat manusia.

Manusia dalam Islam di tempatkan sebagai makhluk yang memilki kemuliaan dan keutamaan, memiliki harkat dan martabat yang tinggi. Pada sistem HAM Islam mengandung prinsip-prinsip dasar tentang persamaan, kebebasan dan penghormatan terhadap sesama manusia. Apapun warna kulit, dari manapun asalnya, dan apapun agama yang dianut. Sampai-sampai Malaikat pun harus menghormatinya (QS AlBaqarah: 34, Al-a'raf:11). Bersamaan dengan pemberian status sebagai "mahluk yang unggul"

Hak-hak asasi manusia memperoleh landasan dalam Islam melalui ajarannya yang paling utama, yaitu Tauhid (mengesakan Tuhan). Karena itu, hak-hak asasi manusia dalam Islam lebih dipandang dalam perspektif theosentris. Walau demikian, ajaran tauhid tersebut berimplikasi pada keharusan prinsip persamaan, persaudaraan dan keadilan antar sesama manusia, dan prinsip kebebasan manusia. Selain prinsipprinsip yang bersifat menjunjung tinggi harkat dan martabat manusia adalah kritik Islam atas ketidakadilan, ketimpangan sosial, dan diskriminasi. Al-Qur'an menyampaikan kritik ini seperti ketidakadilan ekonomi dalam pernyataan "kekayaan tidak boleh berputar di kalangan orang-orang kaya saja" (QS 59:7). Jadi, persamaan hak, keadilan, tolong-menolong, dan persamaan di depan hukum adalah prinsipprinsip kunci yang sangat diperhatikan di dalam Syari'ah. Dalam sejarah peradaban Islam, prinsip-prinsip ini dipegang oleh umat Islam sebagai cara hidup bermasyarakat, berbangsa, dan bernegara. Prinsip tersebut telah menjadi landasan bagi pembentukan peradaban masyarakat Muslim awal, sehingga menempatkan dunia Islam beberapa abad di depan barat. Wallu a'lam bi al-shawab.

\section{DAFTAR PUSTAKA}

Syah, Ismail Muhammad, dkk. Filsafat Hukum Islam (Cet. II; Jakarta: Bumi Aksara,1992) Syarifuddin Amir, Ushul Fiqh Jilid 1, Kencana. 2008

Dalizar putra. 1995. Hak Asasi Manusia Menurut Al-Quran, Jakarta: PT. Al-Husna Zikra

Nasution, Harun dan Bahtiar Effendi. Hak Asasi Manusia Dalam Islam. Jakarta : Yayasan Obor Indonesia. 1987

Hakim, M. Luqman. Deklarasi Islam Tentang HAM. Surabaya : Risalah Gusti. 1993 
ash Shiddieqy, T. Muhammad Hasbi. Islam Dan Hak Asasi Manusia, Semarang :PT. Pustaka Rizki Putra. 1999 